\title{
A Reply to Beatriz Plaza's 'The Guggenheim-Bilbao Museum Effect'
}

\author{
MARÍA V. GÓMEZ AND SARA GONZÁLEZ
}

This paper argues against Beatriz Plaza's (1999) reply to María V. Gómez's (1998a) article on urban regeneration strategies in Glasgow and Bilbao. The author is very grateful to Beatriz Plaza for her interest and subsequent reply to her previous words. The current re-reply attempts to show that, while being an interesting approach to the Guggenheim effect, Beatriz Plaza's reply does not address the crucial points related to the museum, stated in the original article.

The article questioned whether urban strategies that focus on cultural infrastructure investment and place marketing were a good mechanism for stimulating cities to recover. Beatriz Plaza's reply is entirely based on the benefits produced by the numbers of visitors to Bilbao, but this was never a main point of the previous argument. In fact, what the article said about Glasgow is: 'There is no doubt that this strategy has had dividends in respect of the number of visitors to the city ... it is also undeniable that the image of Glasgow, both within and outside the city, has been radically reconstructed' (p. 118). The potential success of Bilbao as an important tourist destination was not in question there, as it was not in some of the author's later work (see, for instance, Gómez, 1998b; 2000; González, 2000). We do not deny that the Guggenheim Museum has changed Bilbao's former image, which was largely associated with either pollution or political violence, making it the new symbol of the city worldwide. It is economic revitalization, regarded as an almost automatic outcome of projects such as the Guggenheim Museum, that was called into question. It is the risky use of 'urban flagships' in a context of serious decline, as much as the subsequent political discourses built up around 'success stories' which stress that these are the key to prosperity, that were - and still are — in dispute.

Apart from not addressing the main points and doubts of the former article, Beatriz Plaza's statements are debatable for three different reasons. First, the importance she gives to what she calls 'the uniqueness of cultural investment' is questionable. Allegedly, this is the element on which the positive externalities of a cultural facility mainly depend (1999: 591). However, the extent to which the Guggenheim Museum is unique remains at best uncertain. In April 2001 the architect, Frank Gehry, presented his design for a new Guggenheim branch. According to Matthew DeBord (2000), 'there will be more Bilbaos - architecturally and financially ... If Kren's and the Guggenheim get what they want, New York will have a Gehry museum by 2007'. So there will be another Guggenheim museum designed by Frank Gehry, the same architect, with a very similar design which will also be made of titanium according to the model which was recently exhibited in Manhattan, as Beatriz Plaza herself admitted more recently (2000). So what exactly is unique?

While this is an extreme case, Amin and Malmberg (1994) point out how achieving uniqueness is becoming more and more difficult, since there are obvious limits to the 


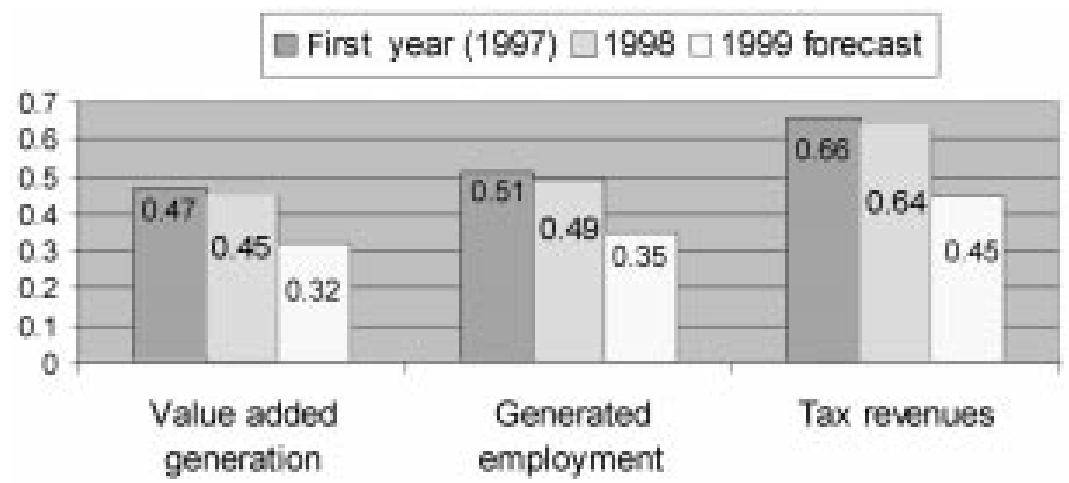

Figure 1 Estimated impacts of the Gugenheim Museum on the Basque economy (source: Bilbao Metrópoli 30, 1999)

possible range of [cultural] projects. The risk of failure is even higher once places are forced to copy each other, as the barrel of new ideas becomes depleted (see also Harvey, 1989; 1994). The future Guggenheim in Manhattan after Bilbao's Guggenheim would illustrate this in the most tangible possible way. Furthermore, as Griffiths (1998: 44) remarks, far from projecting distinctive identities, re-imaging strategies of this type have tended overwhelmingly to homogenize place, with an endless repetition of standard devices from advertising slogans to building types. Criticisms of uniformity and convergence in opposition to local variety and differentiation are especially relevant in the case of the Basque Country, where there is a strong national identity. ${ }^{1}$

Second, the Guggenheim's alleged multiplying effects in the city of Bilbao are not as positive as Plaza declares, at least in the medium term. If the number of visitors exceeded the most optimistic expectations in the first year of operation, an estimate carried out in 1999 by an international consulting firm and the local association 'Bilbao Metrópoli 30' pointed to a decrease in the 'Guggenheim effect' for the Basque economy, as Figure 1 shows. Apart from this, according to critical voices, the Guggenheim approach has incorporated a strictly consumption-oriented view, with a serious disregard for the museum becoming a propulsive engine for the development of a cultural sector (Rodríguez et al., 2001). It is argued in this sense that the capacity of the museum to create local links would require a much greater degree of autonomy vis-à-vis the New York Guggenheim office, instead of operating like a mere branch plant franchise. In terms of financing, the Guggenheim has also been criticized for taking over most of Bilbao's public budget for cultural activities (Zallo, 1995).

Moreover, apart from cultural aims, the main purpose of the museum was to attract new economic activity within the city in the form of advanced services, as was emphasized from the beginning of the project. It is still too soon to assess the museum's real economic impact, but so far it is not possible to regard it as successful (see, for instance, Esteban, 2000: 248; Rodríguez et al., 2001).

Third and finally, there are further threats surrounding the Guggenheim Museum's success, stemming from the political atmosphere after the end of the secessionist group ETA's ceasefire, which not only affects Bilbao but the Basque Country as a whole. In this respect, one member of the association of rural tourism remarked how in terms of visitors the ceasefire effect was far more relevant than the Guggenheim effect (El Correo, 2000; also El País, 2000).

All in all, Beatriz Plaza did not discuss Gómez's former article. She concentrated on what was never questioned, the fact that Bilbao has completely changed its image 
worldwide, with a subsequent positive effect in terms of visitors to the city. We claim that any approach to urban regeneration practices must be more cautious, particularly when as in this case - it is still too early to assess their real impact on the economic and social recovery of the city.

María V. Gómez (mgomez@polsoc.uc3m.es), Departamento de Ciencia Política y Sociología, Universidad Carlos III, Calle Madrid 126, 28093 Getafe, Madrid, Spain and Sara González (cibgoces @1g.ehu.es), Departamento de Sociología, Universidad del País Vasco, Barrio Sarriena s/n 48940 Leioa, Bizkaia, Spain.

\section{References}

Amin, A. and A. Malmberg (1994) Competing structural and institutional influences on the geography of production in Europe. In A. Amin (ed.), Post-Fordism: a reader, Blackwell, Oxford.

Bilbao Metrópoli 30 (1999) Informe annual de progresso. Bilbao Metrópoli 30.

DeBord, M. (2000) Breaking the frame. Feed Magazine 5 June 2000 (on-line) at http:// www.feedmag.com/essay/es330lofi.html.

El Correo (2000) El efecto tregua ha tenido más impacto que el 'efecto Guggenheim'. El Correo 18 September, 12.

El País (2000) Turismo a la Baja. El País (Negocios) 3 December, 7.

Esteban, M. (2000) Bilbao, Luces y Sombras del Titanio. El proceso de regeneración urbana del Bilbao Metropolitano. Servicio Editorial UPV, Bilbao.

Gómez, M.V. (1998a) Reflective images: the case of urban regeneration in Glasgow and Bilbao. International Journal of Urban and Regional Research 22.1, 106-21.

- (1998b) Regeneración urbana. In M.J. González, R. Ramos, M.V. Gómez, C. Dolç, L. Cortés and M. Saravia, El malestar urbano en la gran ciudad, Talasa Ediciones - Fundación Cultural COAM, Madrid.

— (2000) El marketing urbano. Documentación Social 119 (April-June), 199-211.

González, S. (2000) Postindustrial images in Bilbao: analysing promotional literature of an urban development corporation. Paper presented at the Annual Meeting of the Association of American Geographers, Pittsburgh, April.

Griffiths, R. (1998) Making sameness: place marketing and the new urban entrepreneurialism. In N. Oatley (ed.), Cities, economic competition and urban policy, Paul Chapman Publishing Ltd, London.

Harvey, D. (1989) From managerialism to entrepreneurialism: the transformation in urban governance in late capitalism. Geografiska Annaler 71 B.1, 3-17.

- (1994) The invisible political economy of architectural production. In O. Bouman and R. Van Toorn (eds.), The invisible in architecture, Academy Editions, London.

McNeill, D. (2000) McGuggenisation? National identity and globalisation in the Basque Country. Political Geography 19, 473-94.

Plaza, B. (1999) The Guggenheim-Bilbao Museum effect: a reply to María V. Gómez' 'Reflective images: the case of urban regeneration in Glasgow and Bilbao'. International Journal of Urban and Regional Research 23.3, 589-92.

- (2000) Evaluating the influence of a large cultural artifact in the attraction of tourism. The Guggenheim Museum Bilbao case. Urban Affairs Review 36, 264-74.

Rodríguez, A., E. Martínez and G. Guenaga (2001) Uneven redevelopment: new urban policies and socio-spatial fragmentation in metropolitan Bilbao. European Urban and Regional Studies 8.2, $159-76$.

Zallo, R. (1995) Industrias y políticas culturales en España y País Vasco. Servicio Editorial UPV, Bilbao. 